June 1986

\title{
Effects of Vasoactive Intestinal Peptide and Nerve Growth Factor on Rat Osteosarcoma Cells
}

Monica Ann Fisher

Follow this and additional works at: https://opencommons.uconn.edu/sodm_masters

\section{Recommended Citation}

Fisher, Monica Ann, "Effects of Vasoactive Intestinal Peptide and Nerve Growth Factor on Rat Osteosarcoma Cells" (1986). SoDM Masters Theses. 74.

https://opencommons.uconn.edu/sodm_masters/74 
Effects of Vasoactive Intestinal Peptide And Nerve Growth Factor On Rat Osteosarcoma Cells

Monica Ann Fisher, D.D.S., M.S., B.S.

The University of Connecticut

1986

This research is submitted as partial fulfillment of the requirements for the orthodontic certificate. 
Effects of Vasoactive Intestinal Peptide And Nerve Growth Factor On Rat Osteosarcoma Cells

\section{Monica Fisher}

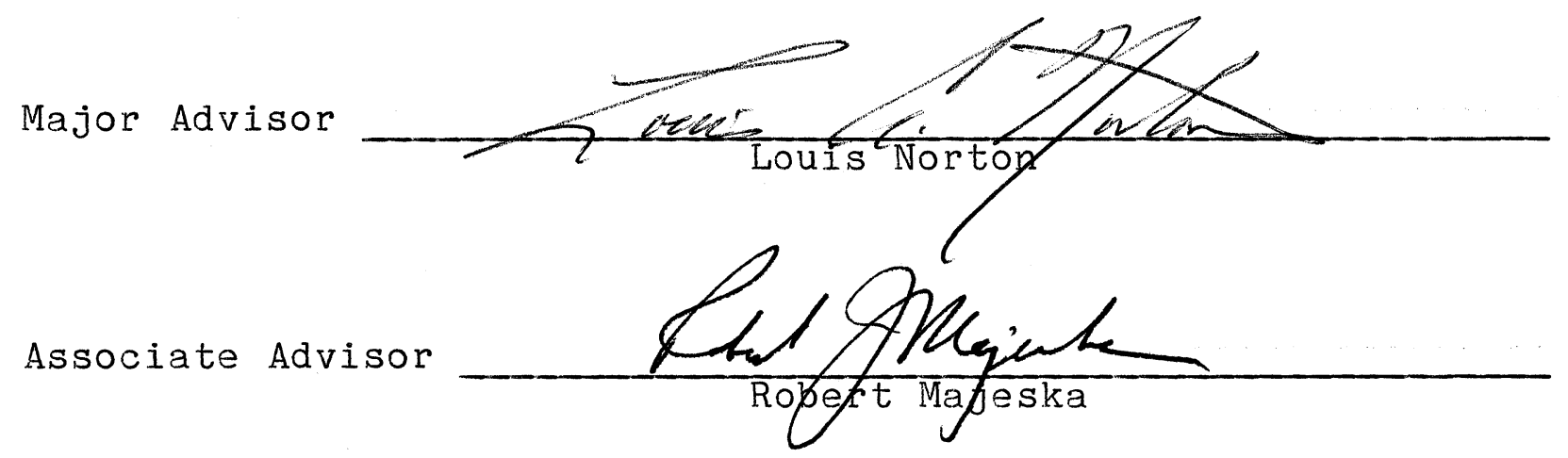

Associate Advisor Millain B. Cpholt 


\section{ABSTRACT}

Studies of limb regeneration have implicated the nervous system in promoting osteogenesis. The neurotrophic hypothesis states that neurons synthesize a substance, called a neurotrophic factor, which is transported to distant target organs or tissues.

The objective of this study was to investigate the direct neural involvement in osteogenesis. This study utilized in vitro cell culture techniques, focusing on two known neurotrophic substances, nerve growth factor (NGF) and vasoactive intestinal peptide (VIP). The effect of these agents on the growth or phenotypic expression of the permanent, clonal osteoblastic cell Iine, Rat Osteosarcoma (ROS 17/2.8) cells was assesśed. Growth of the ROS 17/2.8 cells was determined by the cell number (measured by the coulter counter) and the osteoblastic differentiation was determined by the specific biochemical assay of alkaline phosphatase (AP, a specific osteoblastic marker). The ROS $17 / 2.8$ cells were pre-incubated for 2 days in a culture medium consisting of modified Ham's F-12, 1\% kanamycin sulfate and 5\% fetal bovine serum (FBS). During the experimental period the cells were maintained with Ham's F-12, 2\% FBS, 1\% kanamycin and the test agent. The hypothesis was that the addition of VIP and NGF alters the AP specific activity (Sp Ac) or cell number of the ROS $17 / 2.8$ cells.

NGF and VIP had the following direct effects on osteoblastic growth and differentiation:

1. VIP increased the Ap Sp Ac and cell number, when measured sixty hours following the initial addition of five doses of $0.165 \mathrm{ug} / \mathrm{ml}$ at 12 hour intervals. This condition decreased 
the protein content. VIP had a similar effect when added in a single dose of $0.825 \mathrm{ug} / \mathrm{ml}$.

2. VIP increased the AP Sp Ac and cell number, and decreased the protein content when measured seventy hours following the addition of a single dose $(0.50 \mathrm{ug} / \mathrm{ml}$ and $1.0 \mathrm{ug} / \mathrm{ml})$.

3. NGF inhibited the AP Sp Ac and increased the cell number and protein content when measured sixty hours following the addition of a single dose $(0.025 \mathrm{ug} / \mathrm{ml})$.

4. The phosphodiesterase inhibitor, isobutylmethylxanthine (IBMX), either alone or in combination with other agents decreased AP Sp Ac.

5. The effect of VIP in increasing AP Sp Ac was more pronounced in the presence of IBMX and NGF.

These results are consistent with the hypothesis that the osteoblast responds directly to the neurotrophic substances VIP and NGF . 


\section{INTRODUCTION}

The objective of this research was to investigate whether vasoactive intestinal peptide (VIP) and nerve growth factor (NGF) act as direct regulators of skeletal cell physiology. To test this hypothesis, the effects of VIP and NGF on the differentiation or proliferation of rat osteosarcoma (ROS) 17/2.8 permanent, clonal osteoblastic cell line were examined.

Nerves regulate the growth, maintenance and repair of target organs or tissues, probably via specific chemical substances (Dubner et al., 1978). This relationship, in which nerve cells and target cells interact so as to influence the structure or function of either member, is called neurotrophism (Drachman, 1974).

The neurotrophic hypothesis (Singer, 1978) states, neurons synthesize a substance, called a neurotrophic factor which is transported to distant target organs or tissues. Much of the evidence for neurotrophism comes from regeneration studies.

Regeneration of an amputated $1 \mathrm{imb}$, has been reported in the newt (Singer, 1952), rats (Becker, 1972; Libbin et al., 1979), mice (Neufeld, 1980) and children (Douglas, 1972; Illingworth, 1974; Rosenthal et al., 1979).

Singer (1952) postulated that the role of nerves in regeneration is mediated by a chemical trophic factor. Both sensory and motor fibers are able to maintain limb regeneration al though a larger number of motor fibers appear to be necessary (Singer, 1946, 1952). The intensity of regeneration is determined by the number of nerve fibers present (Guth, 1969). When nerves grow into an 
amputated aneurogenic stump, regeneration is accelerated (Yntema, 1959). When the nerves are resected after partial regeneration has occured, further growth is prevented and the partial regenerate may regress to the original amputation site (Singer and Craven, 1948). Thus, the nervous system has been implicated in osteogenesis, bone formation and resorption. Since regeneration studies involve the total system there is the complication of tissue interactions. Therefore, a direct connection between limb regeneration and bone growth is not proven in regeneration studies. Utilizaton of the cell culture technique would be helpful when investigating a direct effect.

There have been conflicting reports of possible neural involvement in skeletal physiology. Some of the studies indicating that the neural involvement is not important in skeletal physiology include the findings of Corbin and Hinsey (1939), that the skeleton can be maintained even when completely denervated ( $1-3$ sacral dorsal and lumbar sympathectomy in cats). Also, some investigators did not find any changes in long bone growth in thoracolumbar sympathectomized cats (Harris and McDonald, 1936; Cannon et al.,, 1929), rats (Bacq, 1936), goats (Bisgard, 1938), dogs or lambs (Harris and McDonald, 1936). However, Harris and McDonald (1936) stated that muscular activity was essential to normal growth and that sympathectomy would not produce visible changes in leg length in cases of extensive paralysis. Ashton (1980) reported osteogenesis occured in millipore filter chambers in the total absence of neural cells. However, the "in vivo" environment, seemed essential for this process.

Denervation studies should be interpreted carefully since such 
experiments result in muscular, circulatory, neuronal and disuse effects. During surgical denervation, there is the complicating factor of muscle damage, which is important when interpreting the results. Also, in regional migratory osteoporosis, which is transient localized demineralization, the muscles overlying the affected area are denervated. Thus, this in vitro study of the neural involvement via NGF and/or VIP is an alternate approach to this question regarding skeletal physiology.

The first neurotrophic substance to be identified was NGF (Bueker, 1948). NGF has been proposed as a possible agent regulating trophic interactions in the peripheral nervous system (Varon and Bunge, 1978). Greene and Shooter (1980) suggest a possible extraneuronal role for NGF. Specific binding sites for NGF have been found in the brain, adrenal gland, heart, abdominal aorta, liver, spleen, uterus, kidney, diaphragm and skeletal muscle (Frazier et al., 1974).

A possible role for $N G F$ in bone remodeling was reported by Teitelbaum et a1. (1978). The effects of NGF on maintaining cranial bone and cartilage as differentiated neural crest cells were discussed by Coulombre et al. (1974).

Weis and Weis (1970) found an increase in the length of regenerating limbs and in the rate of digit formation in Ambystoma following administration of $\mathrm{NGF}$.

Saide et al. (1975) observed that patients with Paget's disease (intense bone remodeling and rapid proliferation of fibroblasts) have higher serum concentrations of NGF.

VIP is a single chain peptide of 28 amino acids, mol. wt. 
3300. VIP was first isolated from porcine small intestine (Said and Mutt, 1970) and has since been localized within neurons by radioimmunological and immunohistochemical methods (Fuxe et al., 1977). VIP is synthesized as part of the polyprotein, pre-proVIP. Tsukada et al. (1985) have isolated and determined the structure of the human vasoactive intestinal polypeptide gene. Marie et al. (1985) found that the tyrosyl residue (Tyr-22) and the localized hydrophobic features of VIP are critically involved in the function of VIP. In the periphery, post-ganglionic parasympathetic neurons containing VIP innervate blood vessels and secretory epithelial cells where electrical stimulation results in an increase in VIP, which causes vasodilation and secretion in salivary glands (Fahrenkrug, 1979; Uddman et a1., 1980). Scott and Baum (1985) reported that CAMP and calcium were involved in the exocrine protein secretion induced by VIP in rat parotid cells. VIP also synergistically stimulated parotid secretion when combined with substance $P$, another neurotransmitter and a sialogogue (Ekstrom and Olgart, 1986).

VIP is a putative neurotransmitter in the system referred to as the peptidergic nervous system (Sundler et al., 1980) or the so called VIPergic system (Polak and Bloom, 1982). Under conditions of electrical blockade, Brenneman and Eiden (1986) demonstrated the neurotrophic action of VIP on neuronal survival. VIP has a large spectrum of important biologic activities including it's effect on blood flow, smooth muscle relaxation, exocrine secretion and endocrine, neuroendocrine activity.

For certain agents (PTH, PGE) the first step in the stimulation of bone resorption is probably binding of the hormone to specific 
cell surface receptors, followed by the activation of adenylate cyclase and increases in cAMP. Hohmann and coworkers (1983) found that VIP causes a dose-dependent increase in bone resorption via a cAMP-dependent, prostaglandin (PG) independent mechanism. It has been suggested that most agents that increase cAMP levels in bone do so via the osteoblast, which then act to stimulate and/or recruit the osteoclast, resulting in bone resorption (Rodan and Martin, 1981). Hohmann and Tashjian (1984) found that human osteosarcoma cells respond to VIP with an increased production of cAMP which is mediated by specific surface receptors for VIP. McSheehy and Chambers (1986) report that osteoblastic cells mediate osteoclastic responsiveness to $\mathrm{PTH}$, which is also consistent with Rodan and Martin's (1981) hypothesis.

Some clinical findings of relevance are: 1.) The report of a case of VIP-secreting ganglioneuroma with the predominant clinical picture of growth failure with intermittent secretory diarrhea and soiling. The short stature with severe growth failure was a dominant feature in the absence of weight loss, malabsorptin or ill health (Granot et al., 1983). 2.) Kaplan and coworkers (1980) reported earlier on a VIP secreting tumor of childhood which included in the clinical picture, failure to thrive, with the child's height and weight below the third percentile.

Laburthe et al. (1986) reported that AC-Tyr1 hGRF (human growth hormone-releasing factor with position 1 substituted Ac-Tyr1 analog) is a competitive VIP antagonist in the rat. N-terminal histidine (position 1, His1) is important for peptide interaction with VIP receptors. Chihara and coworkers (1984) report the stimulation of 
growth hormone by VIP in acromegaly. Previous studies found that VIP stimulates GH secretion from GH-secreting pituitary adenoma in vitro (Chihara et al., 1982; Matsushita et al., 1981). Again, these conflicting reports, on the possible involvement of the nervous system indicate the complexity of the total system. Therefore, utilization of cell culturing may provide useful information regarding a direct effect.

The rat osteosarcoma clonal cell lines (ROS) were selected on the basis of parathyroid hormone-sensitive adenylate cyclase. These cells express the following osteoblastic characteristics: elevated AP, $1 \propto, 25-(\mathrm{OH})_{2}$ vitamin $D_{3}$ receptors, bone $\gamma$-carboxyglutamic acid protein synthesis stimulated by $1 \propto, 25-(\mathrm{OH})_{2}$ vitamin $D_{3}$, osteogenesis in subcutaneous tumors and implanted Millipore filter chambers (Majeska et al., 1980). In ROS $17 / 2.8$ cells, proliferation and phenotypic expression (exemplified by cell number and AP activity) is modulated by hormones known to affect bone (e.g. PTH). Even though differentiation is coupled to growth arrest, the arrest of growth does not necessarily result in differentiation.

Therefore, the goal of this study is to provide insight into possible direct effects of the nervous system on osteoblasts. Specifically, the effect of VIP and NGF on growth and differentiation was investigated. 
Objective and Hypothesis

The objective of this study is to investigate the neural involvement in osteogenesis. As discussed under the Introduction section, neurotrophism has been investigated mostly via regeneration studies of the limb. These in vivo studies are difficult to interpret because of the muscular, circulatory, neuronal and disuse effects. This study utilized in vitro culture techniques; focusing on two known neurotrophic substances, NGF and VIP. The effect of these agents on growth or phenotypic expression of the permanent, clonal osteoblastic cell line, Rat Osteosarcoma (ROS 17/2.8) were assessed by determining the cell number and by the specific biochemical assay of alkaline phosphatase (AP). Alkaline phosphatase is a specific osteoblastic marker, used to determine osteoblast differentiation.

In summary, the objective was to determine if VIP and NGF effect the differentiation or proliferation of ROS 17/2.8 cells. The hypothesis is that the addition of VIP and NGF alters the AP specific activity or cell number of ROS 17/2.8 cells. 
MATERIALS AND METHODS

Materials

Cel1 culture medium, serum and antibiotics were purchased from GIBCO, Grand Island, NY. Culture plasticware was from COSTAR, Cambridge, MA. Hepes, 2-amino-2-methyl-1-propanol, disodium pnitrophenylphosphate, p-nitrophenol, vasoactive intestinal peptide (VIP), Tris (hydroxymethyl)-aminomethane and bovine serum albumin (BSA) were from Sigma, St. Louis, MO. Triton X-100 was from Rohm and Haas, Philadelphia, PA. Isobutylmethylxanthine (IBMX) was from Aldrich Chemical Co., Milwaukee, WI. 7S-Nerve Growth Factor was from Collaborative Research, Inc., Lexington, MA.

Population to be Studied

The permanent, clonal osteoblastic cell line, Rat Osteosarcoma (ROS 17/2.8) cells was utilized to facilitate the study of osteoblastic cells in culture. Cell culture minimizes differences between experiments due to heterogeneity and the loss of phenotypic properties, which are present in organ culture and primary cell cultures.

Cel1 Culture and Maintenance

The maintenance medium consisted of modified Ham's F-12 (Majeska and Rodan, 1982a) containing 1\% kanamycin sulfate and supplemented with either $10 \%$ or $5 \%$ fetal bovine serum (FBS). Cultures were kept at $37^{\circ} \mathrm{C}$ in a humidified $95 \%$ air $/ 5 \% \mathrm{CO}_{2}$ atmosphere, and were subcultured weekly. 


\section{Cell Counting}

For experiments, cell suspensions were prepared at the appropriate density for each experiment, and $1 \mathrm{ml}$ portions were plated in 24 multiwell plates.

The following procedures were performed, to plate out 20,000 cells/well [in a $16 \mathrm{~mm}$ diameter well (P-16) which has a culture area of $2 \mathrm{~cm}^{2}$ and a medium volume of $1 \mathrm{mll}$. First, the medium was aspirated from a P-100 (100 mm diameter culture dish) of confluent ROS cells. Next, $2.0 \mathrm{ml}$ of $0.01 \%$ trypsin was added for 5 minutes, then the trypsin was removed. Next, $0.5 \mathrm{ml}$ of $0.01 \%$ trypsin was added to the culture plates which were placed in the incubator at $37^{\circ} \mathrm{C}$ for 8-10 minutes. This was followed by resuspension of the cells in $10 \mathrm{ml}$ of medium (5\%FBS, 1\% kanamycin). Then the cell suspension was pipetted into a $16 \mathrm{ml}$ tube; the cells were thoroughly mixed by pipetting up and down. With the same pipette, $0.5 \mathrm{ml}$ was removed aseptically and added to $9.5 \mathrm{ml}$ saline $(0.9 \% \mathrm{NaCl})$ in a cuvette. Each sample was counted three times.

The number of cells per milliliter in the test tube was determined by the average count, which is multiplied by 40 because of the following calculation:

Average count (\# of cells) x $10 \mathrm{ml}$ total volume/0.5 ml sample size $\mathrm{x}$

$$
1 / 0.5 \mathrm{ml} \text { coulter counting volume = }
$$

Average count(number of cells) $\times 40=$ number of cells $/ \mathrm{ml}$

The seeding density of $20,000 \mathrm{cells} /$ well, which is equivalent to 10,000 cell $1 \mathrm{~s} / \mathrm{cm}^{2}$ was prepared utilizing the determined number of cells/ml. Since each well contains a medium volume of $1 \mathrm{ml}$, the appropriate number of cells were removed from the test tube and 
placed in a sterile bottle with the correct amount of medium.

For example, if the average cell count was 19,754 cells $\times 40=$ $790,147 \mathrm{cel} 1 \mathrm{~s} / \mathrm{ml}$. In experiment \#1, 100 wells required 20,000 cells/well necessitates 2,000,000 cells/100 wells. Since there were $790,147 \mathrm{cells} / \mathrm{ml}$ a $2.53 \mathrm{ml}$ aliquot was removed and placed in 97.47 ml medium (\%5 FBS, $1 \%$ kanamycin). Then $1 \mathrm{ml}$ of this mixture was added to each of the 100 wells. The preincubation period was 2 days.

At the end of each experiment, the following procedure was used to count the number of cells per $16 \mathrm{~mm}$ well: The medium was first aspirated from each well and the cells were rinsed once with CMFH. Then $0.5 \mathrm{ml}$ of $0.01 \%$ trypsin was added to each well and the plate was incubated at $37^{\circ} \mathrm{C}$ for $8-10$ minutes. Next, $0.5 \mathrm{ml}$ saline $(0.9 \%$ $\mathrm{NaCL}$ ) was added to each well; the cells were resuspended and pipetted into pre-loaded cuvettes containing $9.0 \mathrm{ml}$ saline. Each sample was counted three times. This average count was for the 0.5 $\mathrm{ml}$ aliquots of the $10 \mathrm{ml}$ in each cuvette. Therefore, each average value of the cell counts was multiplied by a factor of 20 , in order to obtain the actual number of cells/well.

\section{Alkaline Phosphatase Assay}

First, the medium was aspirated from the wells; then each well was rinsed once with CMFH, followed by the addition of $0.5 \mathrm{ml}$ of the sample buffer (10mM Tris-HCl, pH 7.5, $0.5 \mathrm{mM} \mathrm{MgCl}_{2}, 0.1 \%$ triton $\mathrm{X}-$ 100) to each well. Next, the wells were scraped with a plastic scraper and the sample were pipetted into plastic test tubes and either kept on ice or frozen until assayed.

Ten microliter aliquots of the sample were placed in duplicate 
test tubes and kept on ice. At time $=0,0.180 \mathrm{ml}$ of the alkaline phosphatase assay mixture containing 0.1 M 2-amino-2-methyl-1propanol, $2 \mathrm{mM} \mathrm{MgCl}_{2}, 2 \mathrm{mM} \mathrm{Na} 2$ p-nitrophenylphosphate ( $\mathrm{Na}_{2} \mathrm{PNPP}$ ) was added, followed by vortexing and incubation in a $37^{\circ} \mathrm{C}$ water bath. The reactions were stopped with $0.8 \mathrm{mI}$ of $1.0 \mathrm{~N} \mathrm{NaOH}$ and the absorbance was read at $410 \mathrm{~nm}$. When using ROS $17 / 2.8$ the reaction is linear for about 20 min with up to 3 ug of protein.

Protein Determination by Coomassie Blue G (Spector,1978):

Duplicate assay tubes were prepared containing 10 ul aliquots of each sample. To each assay tube $100 \mathrm{ul}$ of $\mathrm{H}_{2} \mathrm{O}$ was added. A protein standard curve was prepared using the $500 \mathrm{ug} / \mathrm{ml}$ stock solution of BSA as follows: The BSA stock solution was diluted 1:10 (100 ul of BSA +900 ul of $\left.\mathrm{H}_{2} \mathrm{O}\right)$. A series of tubes (duplicates) were prepared containing $0,1,2,3,4$ or 5 ug of BSA. This is equivalent to $0,20,40,60,80$ or 100 ul of the diluted stock BSA. Each standard is brought up to a volume of 100 ul with $\mathrm{H}_{2} \mathrm{O}$. Then, to each standard tube $10 \mathrm{ul}$ of sample buffer (10 mM Tris-HCl pH 7.5, $0.5 \mathrm{mM} \mathrm{MgCl}_{2}, 0.1 \%$ Triton $\mathrm{X}-100$ ) was added. To all test tubes (samples and standards) $900 \mathrm{ul}$ of the Coomassie Blue G reagent was added. The test tubes were allowed to stand at room temperature for 5 min. Then the absorbance was read in the spectrophotometer at 595 nm. Protein concentrations were determined using standard curves obtained by linear regression analysis. 
Specific Activity of Alkaline Phosphatase Determination

The specific activity ( $\mathrm{Sp} \mathrm{Ac)}$ of alkaline phosphatase (AP) was determined using the following equation:

$\mathrm{Sp} \mathrm{Ac}$ (umole/min/mg protein) $=\left(\mathrm{X}_{\mathrm{ab} 410}-\mathrm{Blank}_{\mathrm{ab} 410}\right) \mathrm{x}$

$0.0574 / \mathrm{T}_{\mathrm{min}} /$ Protein $\mathrm{mg}$; where $\mathrm{T}=15$ minutes in experiment $\# 1$ and \#3 and $T=4$ minutes in experiment \#2, $X=$ mean absorbance at $410 \mathrm{~nm}$, Blank = absorbance at $410 \mathrm{~nm}$ of $180 \mathrm{ul} \mathrm{Buffer}+800 \mathrm{ul} \mathrm{NaOH}, 0.0574$ is derived from the molar extinction coefficient of p-nitrophenol, the reaction product. Values for $\mathrm{Sp}$ Ac were calculated for each well, the means and standard deviations were determined for each group using these values.

Preparation of Substances:

Vasoactive intestinal peptide ( $0.25 \mathrm{mg}$ VIP) was dissolved in $1.0 \mathrm{ml}$ of $0.1 \% \mathrm{HAC}, 0.1 \% \mathrm{BSA}, \mathrm{pH} 4.0$. This was the stock VIP (250 ug VIP/ml HAC-BSA). The control (vehicle) for VIP was HAC-BSA. Nerve growth factor (100 ug NGF) was dissolved in $1.0 \mathrm{ml}$ medium (2\% FBS, 1\% kanamycin). This was the stock NGF (100 ug NGF/ml medium). NO GLASS WAS USED WITH NGF (plastic pipettes were used). The control (carrier-vehicle) for NGF was the culture medium (2\% FBS, 1\% kanamycin).

The stock $20 \mathrm{mM}$ IBMX was prepared by dissolving $4.4 \mathrm{mg}$ IBMX in $1.0 \mathrm{ml}$ of $0.2 \mathrm{~N} \mathrm{NaOH}$. The control (carrier-vehicle) for IBMX was $0.2 \mathrm{~N} \mathrm{NaOH}$. 
Treatment of $17 / 2.8$ Cultures with Vasoactive Intestinal Peptide, Nerve Growth Factor and IBMX

\section{Experiment \#1 Design:}

ROS $17 / 2.8$ cells previously maintained in 10\% FBS were seeded into one 4 well $(16 \mathrm{~mm})$ and four 24 well $(16 \mathrm{~mm})$ plates at a density of $10,000 \mathrm{cell} / \mathrm{s} / \mathrm{cm}^{2}(20,000 \mathrm{cells} / \mathrm{well})$ in 5\% FBS, $1 \%$ kanamycin medium. After 2 days, two-wells were assayed for cell number, and two for alkaline phosphatase and protein. The remaining wells were fed with medium containing $2 \%$ FBS and test agents as shown below. In experiment \#1a, one dose of $0.825 \mathrm{ug} V I P / \mathrm{ml}$ was added to two of the 24 well plates. In experiment \#1b, 5 doses of $0.165 \mathrm{ug} \mathrm{VIP} / \mathrm{ml}$, at 12 hour intervals was added to the two remaining 24 we 11 plates. Sixty hours following the initial addition of the agents, alkaline phosphatase, protein content and cell number were determined.

Figure 1. Experiment \#1 Design

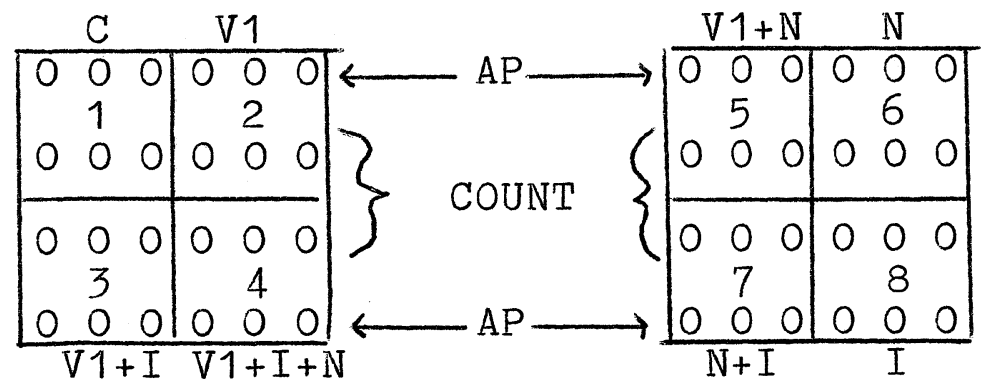

$$
\begin{aligned}
\mathrm{C}= & \text { Control carrier- } \\
& \text { vehicles only. } \\
\mathrm{V} 1= & 1 \text { dose at } \mathrm{t}=0 \text { of } \\
& 0.825 \mathrm{ug} \mathrm{VIP} / \mathrm{ml} \text { in } \\
& \text { each well. } \\
\mathrm{I}= & 0.2 \mathrm{mM} \mathrm{IBMX} . \\
\mathrm{N}= & 0.025 \mathrm{ug} \mathrm{NGF/mI} \mathrm{in} \\
& \text { each well. }
\end{aligned}
$$
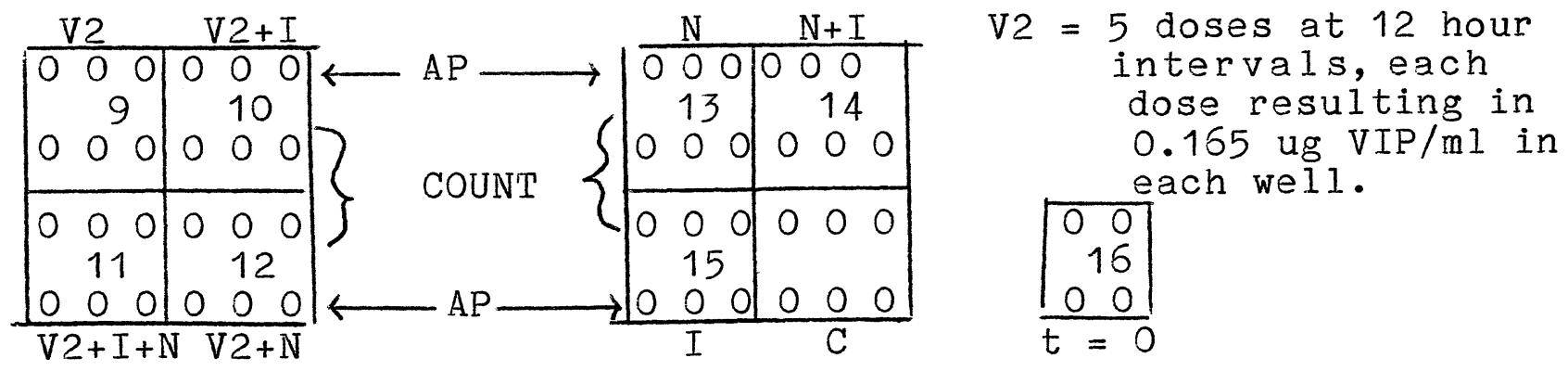


\section{Experiment \#2 Design}

One 4 well $(16 \mathrm{~mm})$ and two 24 well $(16 \mathrm{~mm})$ plates were seeded at 30,000 cells $/ 16 \mathrm{~mm}$ well. The cells were grown for 2 days in $2 \%$ FBS, $1 \%$ kanamycin medium, then fed with $0.2 \% \mathrm{FBS}, 1 \%$ kanamycin medium containing test agents shown below. Ninety-six hours following the addition of the agent, alkaline phosphatase, protein content and cell counts were determined.

Figure 2. Experiment \#2 Design

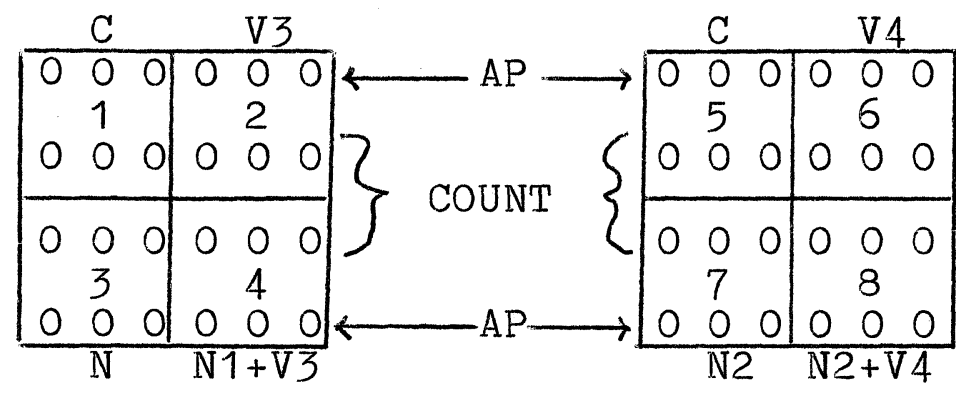

$$
\begin{aligned}
C= & \text { Control } \\
& \text { carrier- } \\
& \text { vehicle }
\end{aligned}
$$

$$
\begin{aligned}
& \mathrm{V} 3=1.0 \mathrm{ug} \mathrm{VIP} / \mathrm{ml} \\
& \mathrm{V} 4=0.5 \mathrm{ug} \mathrm{VIP} / \mathrm{ml} \\
& \begin{array}{ll}
\begin{array}{ll}
0 & 0 \\
0 & 0
\end{array} & \mathrm{~N} 1=0.25 \mathrm{ug} \mathrm{NGF} / \mathrm{ml} \\
\mathrm{t}=0 & \mathrm{~N} 2=0.1 \mathrm{ug} \mathrm{NGF} / \mathrm{ml}
\end{array}
\end{aligned}
$$

\section{Experiment \#3 Design}

Two 24 well (16mm) plates were seeded at a density of 20,000 cell s/16mm well. The cells were grown for 2 days in 5\% FBS, $1 \%$ kanamycin medium, then fed with $2 \%$ FBS, $1 \%$ kanamycin medium containing the concentrations of VIP illustrated in Figure 3. Cell counts, AP and protein measurements were performed 70 hours after the addition of the test agents. 
Figure 3. Experiment \#3 Design

Count:

\begin{tabular}{|lll|lll|}
\hline & $\mathrm{C}$ & \multicolumn{3}{c}{$\mathrm{V} 1$} \\
\hline 0 & 0 & 0 & 0 & 0 & 0 \\
& 1 & & 2 & \\
0 & 0 & 0 & 0 & 0 & 0 \\
\hline 0 & 0 & 0 & 0 & 0 & 0 \\
& 3 & & 4 & \\
0 & 0 & 0 & 0 & 0 & 0 \\
\hline
\end{tabular}

Alkaline Phosphatase:

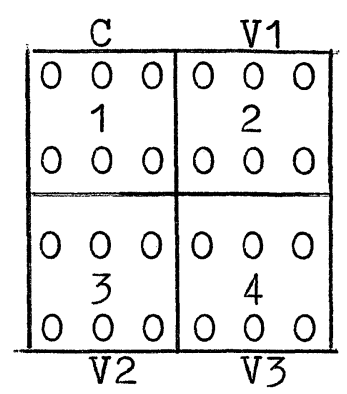

$$
\begin{aligned}
& \mathrm{C}= \begin{array}{l}
\text { Control } \\
\text { carrier }-
\end{array} \\
& \text { vehicle } \\
& \mathrm{V} 1= 0.5 \mathrm{ug} \mathrm{VIP} / \mathrm{ml} \\
& \mathrm{V} 2=1.0 \mathrm{ug} \mathrm{VIP} / \mathrm{ml} \\
& \mathrm{V} 3=1.5 \mathrm{ug} \mathrm{VIP} / \mathrm{ml}
\end{aligned}
$$




\section{RESULTS}

In this study, both of the neural factors, NGF and VIP had direct effects on the ROS cells. In experiment \#1a, the addition of one dose of 0.825 ug VIP/ml produced small increases in AP specific activity and cell number and a decrease in the protein content. In comparison to untreated controls, by the T-test, these were small. Similarly, NGF increased the cell number and protein content; and inhibited AP activity.

The effect of IBMX was marked. When IBMX was compared to the untreated control, using the T-test, there was a decrease in AP specific activity and cell number, and a significant increase in protein content. In Experiment \#1(a+b), al1 of the values of AP Sp Ac which were significantly decreased had IBMX added. IBMX is a phosphodiesterase inhibitor, which inhibits the destruction of cAMP. Binding of a hormone to a membrane receptor induces intracellular CAMP. Cyclic AMP activates protein kinases which phosphorylate intracellular proteins. Cyclic AMP is synthesized from ATP by the plasma membrane bound enzyme, adenylate cyclase, and is rapidly destroyed by phosphodiesterase.

While few of these effects were significant when analyzed by the T-test, the 3-way ANOVA showed a significant effect. The Three-Way Analysis of Variance (3-Way ANOVA) was performed on the values in Table 1 with the results shown in Table 2. When VIP was added a significant difference was found in AP Sp Ac and protein content. When NGF was added, a significant difference was found in AP Sp Ac. When IBMX was added, a significant difference was found in AP Sp Ac, cell number and protein content. When VIP + IBMX was 
added, an interaction was found to affect the protein content. When NGF + IBMX were added, an interaction was found to affect the AP Sp Ac and protein content.

Then, in experiment \#1b, when five doses of $0.165 \mathrm{ug} \mathrm{VIP} / \mathrm{ml}$ was added at 12 hour intervals, there was an increase in AP Sp AC and cell number and a decrease in protein content. Similarly, NGF stimulated AP activity and cell number and inhibited protein content.

The 3-Way ANOVA was performed on the values from Table 3, with the results shown in Table 4. When VIP was added in five doses, at 12 hour intervals, a significant effect was found on AP Sp AC, cell number and protein content. The addition of NGF had a significant affect on cell number. The addition of IBMX affected the AP SP AC and cell number. An interaction was found with VIP + NGF on the AP Sp Ac, cell number and protein content.

In experiment \#2, within one plate, using the T-test to compare $0.25 \mathrm{ug} \mathrm{NGF} / \mathrm{ml}$ to the untreated control, there was a significant increase in cell number, and on the other plate, the addition of 0.1 ug NGF/ml produced a significant decrease in AP Sp AC. However, the variation between controls on the two plates was so large that is was not possible to deduce effects of VIP and NGF.

Experiment \#3 was designed to replicate the experimental conditions in experiment $\# 1 a$, with respect to plating density, and the length of the traatment period. In this experiment, with a larger sample size, the effects were small and not statistically significant, although the direction was the same as experiment \#1. Also, at the highest concentration ( $1.5 \mathrm{ug} V I P / \mathrm{ml}$ ) tested, a reversal of this effect was observed. 
Table 1. Experiment \#1a, Number of Cells/Well, Protein Content and Alkaline Phosphatase Specific Activity Following Addition of Agents to ROS 17/2.8 Cells

[VIP] [NGF] [IBMX] Cell Number/Well $\mathrm{ug} / \mathrm{ml} \quad \mathrm{ug} / \mathrm{ml} \quad \mathrm{mM}$

$x 10^{4}$

$\mathrm{AP} \mathrm{Sp} \mathrm{Ac}$
mg protein
$\mathrm{umol} / \mathrm{min} / \mathrm{mg}$

$\begin{array}{cccccc}0 & 0 & 0 & 6.464 \pm 1.235 & .0770 \pm .0104 .613 \pm .1264 \\ .825 & 0 & 0 & 6.779 \pm 0.965 & .0690 \pm .0017 & .727 \pm .1228 \\ .825 & 0 & .2 & 4.877 \pm 0.922 & .0758 \pm .0023 & .323 \pm .0214^{*} \\ .825 & .025 & .2 & 6.076 \pm 0.730 & .0735 \pm .0221 & .362 \pm .0839 * \\ .825 & .025 & 0 & 6.264 \pm 1.476 & .0813 \pm .0023 & .552 \pm .0643 \\ 0 & .025 & 0 & 7.346 \pm 0.656 & .0990 \pm .0035^{*} .462 \pm .0523 \\ 0 & .025 & .2 & 6.398 \pm 0.361 & .1093 \pm .0014^{*} .236 \pm .0182^{*} \\ 0 & 0 & .2 & 5.728 \pm 0.266 & .1195 \pm .0095^{*} .228 \pm .0047^{*}\end{array}$

All values are the mean $+\mathrm{SD}$.

The test agents were added for 60 hours in $2 \%$ serum.

*Significant difference at P<.05 when compared to untreated controls.

Table 2. Experiment \#1a, Analysis of Variance For Values From Table 1

\begin{tabular}{|c|c|c|c|}
\hline Factor & $\operatorname{AP} \mathrm{Sp}^{\mathrm{F}} \mathrm{Ac}$ & $\begin{array}{l}\text { For Effect On } \\
\text { Cell Number }\end{array}$ & Protein Content \\
\hline VIP & $11.849 * *$ & 1.501 & $46.450 * *$ \\
\hline NGF & $5.097 *$ & 2.004 & 2.151 \\
\hline IBMX & $95.050 * *$ & $5.685^{*}$ & $11.613^{* *}$ \\
\hline VIPxNGF & 0.003 & 0.303 & 0.0116 \\
\hline VIPxIBMX & 0.018 & 0.067 & $12.058 * *$ \\
\hline NGFXIBMX & $9.115^{* *}$ & 0.899 & $9.512^{* *}$ \\
\hline VIPXNGFXIBMX & 0.189 & 1.490 & 1.258 \\
\hline
\end{tabular}


AP Snecific Activity (umol/min/mg)

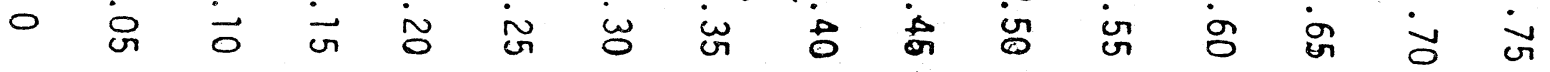
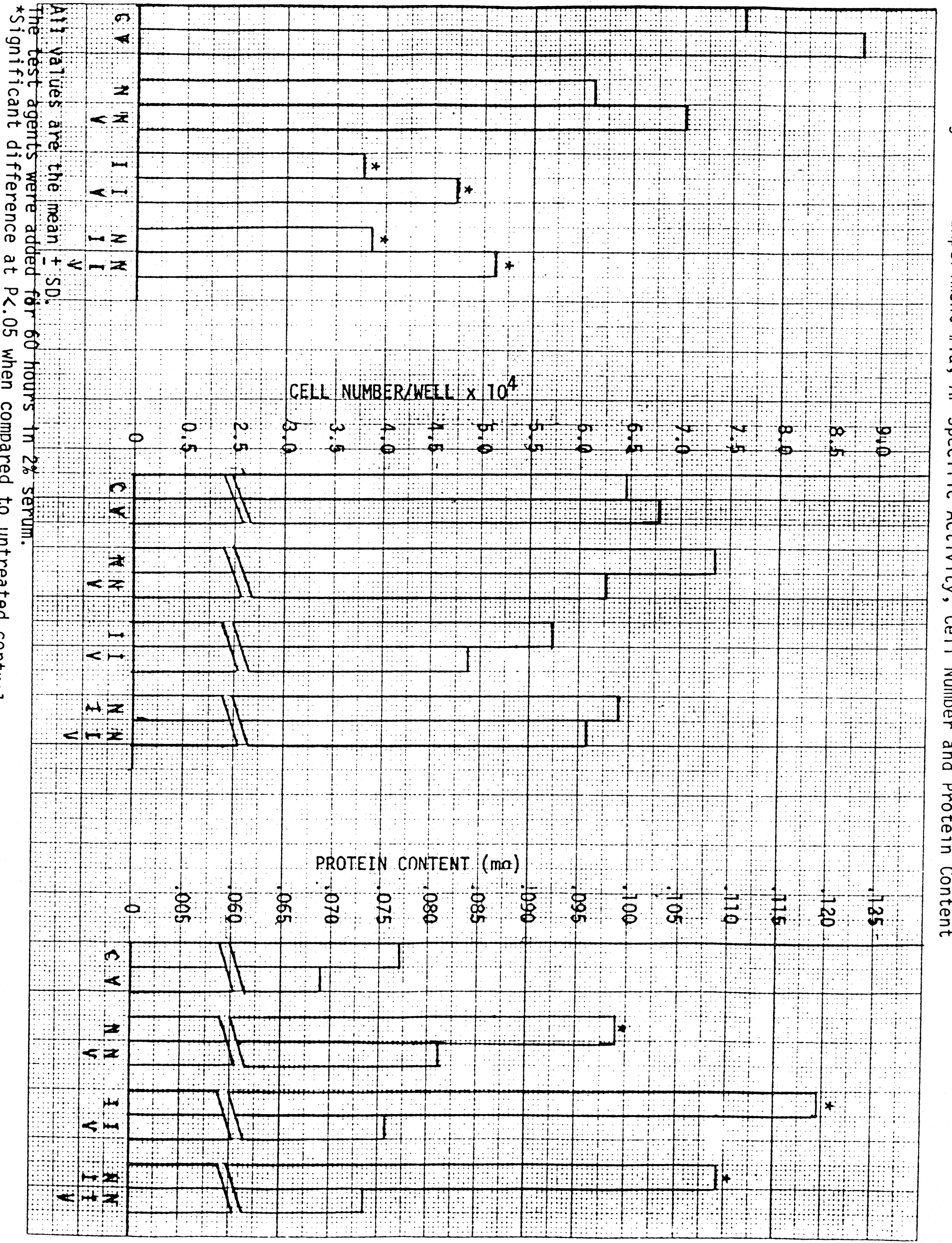
Table 3. Experiment \#1b, Number of Cells/Well, Protein Content and Alkaline Phosphatase Specific Activity Following Addition of Agents to ROS $17 / 2.8$ Cells

\begin{tabular}{|c|c|c|c|c|c|}
\hline $\begin{array}{l}{[\mathrm{VIP}]} \\
\mathrm{ug} / \mathrm{m} 1\end{array}$ & $\begin{array}{l}{[\mathrm{NGF}]} \\
\mathrm{ug} / \mathrm{ml}\end{array}$ & $\underset{\mathrm{mM}}{\left[\begin{array}{c}\mathrm{IBMX} \\
\mathrm{mM}\end{array}\right]}$ & $\begin{array}{l}\text { Cell Number/Wel } \\
\times 10^{4}\end{array}$ & mg Protein & $\begin{array}{l}\mathrm{AP} \mathrm{Sp} A C \\
\text { umol } \mathrm{AC} / \mathrm{min} / \mathrm{mg}\end{array}$ \\
\hline $.165 \times 5$ & 0 & 0 & $7.311 \pm 0.180^{*}$ & $.0662 \pm .0104 *$ & $.722 \pm .1422^{*}$ \\
\hline $.165 \times 5$ & 0 & .2 & $6.424 \pm 0.299^{*}$ & $.0703 \pm .0161 *$ & $.459 \pm .1474$ \\
\hline $.165 \times 5$ & .025 & .2 & $5.384 \pm 1.484$ & $.0977 \pm .0271$ & $.283 \pm .0890^{*}$ \\
\hline $.165 \times 5$ & .025 & 0 & $8.645 \pm 1.371^{*}$ & $.0795 \pm .0188 *$ & $.617 \pm .1154^{*}$ \\
\hline 0 & .025 & 0 & $6.947 \pm 1.077^{*}$ & $.0852 \pm .0037^{*}$ & $.541 \pm .0885 *$ \\
\hline 0 & .025 & .2 & $5.659 \pm 0.677$ & $.0957 \pm .0054^{*}$ & $.299 \pm .0243^{*}$ \\
\hline 0 & 0 & .2 & $3.111 \pm 0.931$ & $.1140 \pm .0162$ & $.243 \pm .0340^{*}$ \\
\hline 0 & 0 & 0 & $4.523 \pm 1.345$ & $.1075 \pm .0028$ & $.397 \pm .0588$ \\
\hline
\end{tabular}

All values are the mean $+S D$

The above initial test agents were added for 60 hours in $2 \%$ serum. * Significant difference at P<.05 when compared to untreated controls.

Table 4. Experiment \#1b, Analysis of Variance For Values From Table 3

\begin{tabular}{|c|c|c|c|}
\hline Factor & AP $\mathrm{Sp}^{\mathrm{F} \text { Valu }}$ & $\begin{array}{l}\text { For Effect On } \\
\text { Cell Number }\end{array}$ & Protein Content \\
\hline VIP & $12.814 * *$ & $22.361 * *$ & $11.821 * *$ \\
\hline $\mathrm{NGF}$ & 0.235 & $10.956 * *$ & 0.000 \\
\hline IBMX & $35.051 * *$ & $18 \cdot 527^{* *}$ & 2.326 \\
\hline IIPXNGF & $8.215^{* *}$ & $8.646 * *$ & $9.947^{* *}$ \\
\hline IPXIBIMX & 1.438 & 0.829 & 0.0428 \\
\hline JGFXIBMX & 0.916 & 2.000 & 0.487 \\
\hline$P \times N G F \times I B M X$ & 0.011 & 2.464 & 0.150 \\
\hline
\end{tabular}

Significant effect of factor or factors (axb) on AP Sp Ac, Cell Number and/or Protein Content at $* * P<.01 * \mathrm{P}<.05$ 
AP Specific Açtivițy (umol/min/mg)

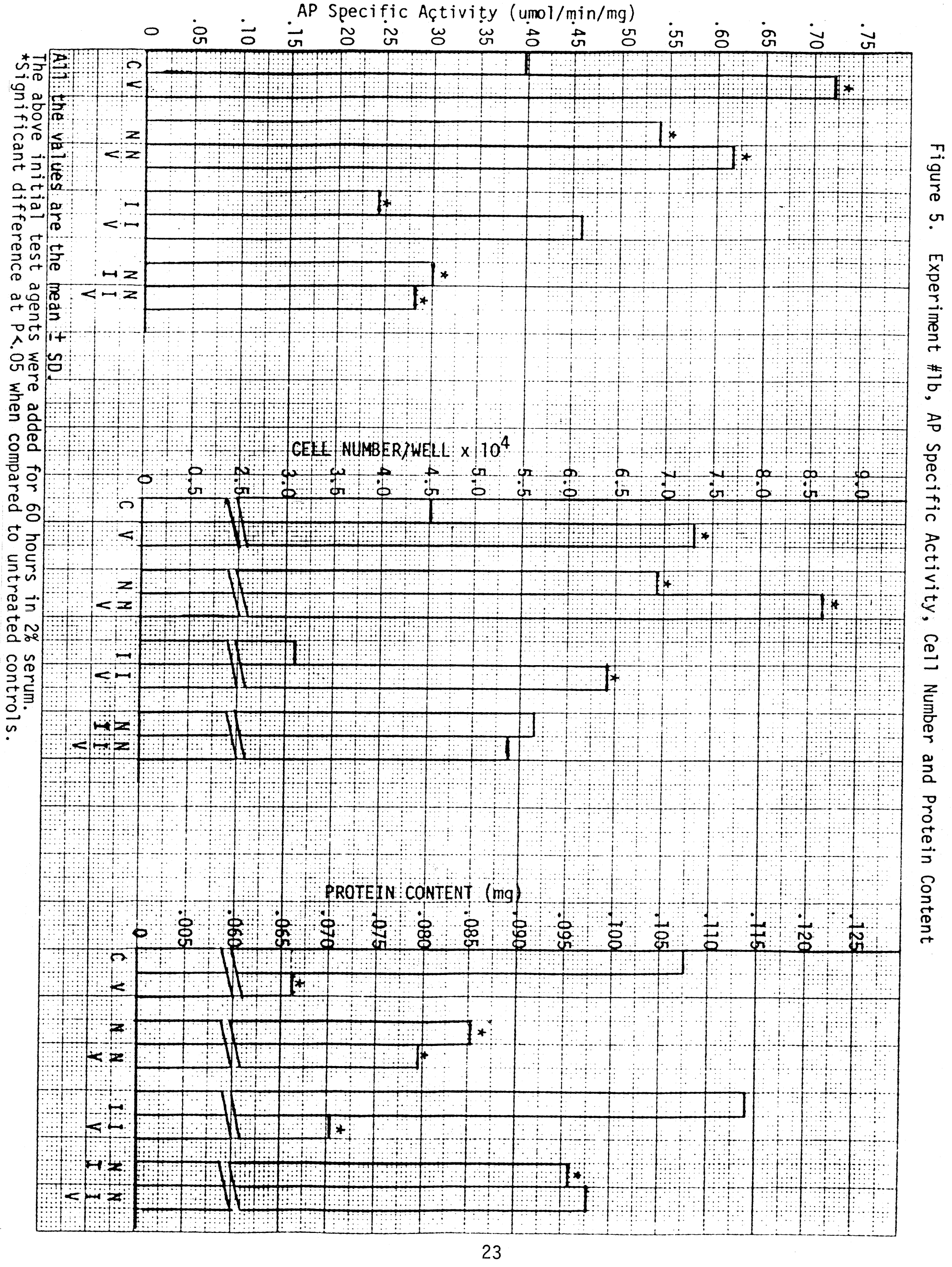


Table 5. Experiment \#2, Number of Cells/We11, Protein Content and Alkaline Phosphatase Specific Activity Following Addition of VIP and NGF to ROS 17/2.8 Cells

\begin{tabular}{|c|c|c|c|c|}
\hline $\begin{array}{l}{[\mathrm{VIP}]} \\
\mathrm{ug} / \mathrm{ml}\end{array}$ & $\begin{array}{l}{[\mathrm{NGF}]} \\
\mathrm{ug} / \mathrm{m} 1\end{array}$ & $\begin{array}{l}\text { Cell Number/Well } \\
\times 10^{4}\end{array}$ & mg Protein & $\begin{array}{l}\text { AP Sp AC } \\
\text { umol/min/mg }\end{array}$ \\
\hline 0 & 0 & $10.110 \pm 2.417$ & $.037 \pm .0113$ & $2.298 \pm .4152$ \\
\hline 1.0 & 0 & $14.226 \pm 2.826$ & $.043 \pm .0047$ & $2.144 \pm .3629$ \\
\hline 0 & .25 & $14.171 \pm 1.836 *$ & $.043 \pm .0078$ & $2.163 \pm .4383$ \\
\hline 1.0 & .25 & $14.351 \pm 2.642$ & $.044 \pm .0120$ & $2.095 \pm .5401$ \\
\hline 0 & 0 & $14.455 \pm 1.874$ & $.043 \pm .0168$ & $2.863 \pm 1.4490$ \\
\hline .5 & 0 & $16.039 \pm 1.211$ & $.047 \pm .0184$ & $2.300 \pm .8287$ \\
\hline 0 & .1 & $13.905 \pm 2.789$ & $.053 \pm .0100$ & $1.716 \pm .3012^{*}$ \\
\hline .5 & .1 & $16.166 \pm 3.283$ & $.053 \pm .0245$ & $2.479 \pm 1.1844$ \\
\hline
\end{tabular}

All values are the mean $+S D$.

The above test agents were added for 96 hours in $0.2 \%$ serum medium. * Significant difference at P<.05 when compared to the untreated controls.

Table 6. Experiment \#3, Number of Cells/Well, Protein Content and Alkaline Phosphatase Specific Activity Following Addition of VIP to ROS $17 / 2.8 \mathrm{Cel} 1 \mathrm{~s}$

[VIP] Cell Number/Well

ug/m1 $\quad \times 10^{4}$ umol AP/min mg Protein

$\begin{array}{rrrrr}0 & 4.100 \pm 0.945 & .064 \pm .0099 & .057 \pm .0050 & 1.172 \pm .1294 \\ .5 & 4.544 \pm 0.558 & .068 \pm .0081 & .053 \pm .0089 & 1.386 \pm .2964 \\ 1.0 & 5.021 \pm 0.817 & .063 \pm .0069 & .048 \pm .0108 * & 1.445 \pm .4762 \\ 1.5 & 4.649 \pm 1.056 & .057 \pm .0115 & .052 \pm .0077 & 1.125 \pm .1570\end{array}$

All values are the mean $+\mathrm{SD}$. VIP was added for 70 hours in $2 \%$ serum medium. * Significant difference at P<.05 when compared to untreated controls. 
Figure 6. Experiment \#3, AP Specific Activity, Cell Number and Protein Content

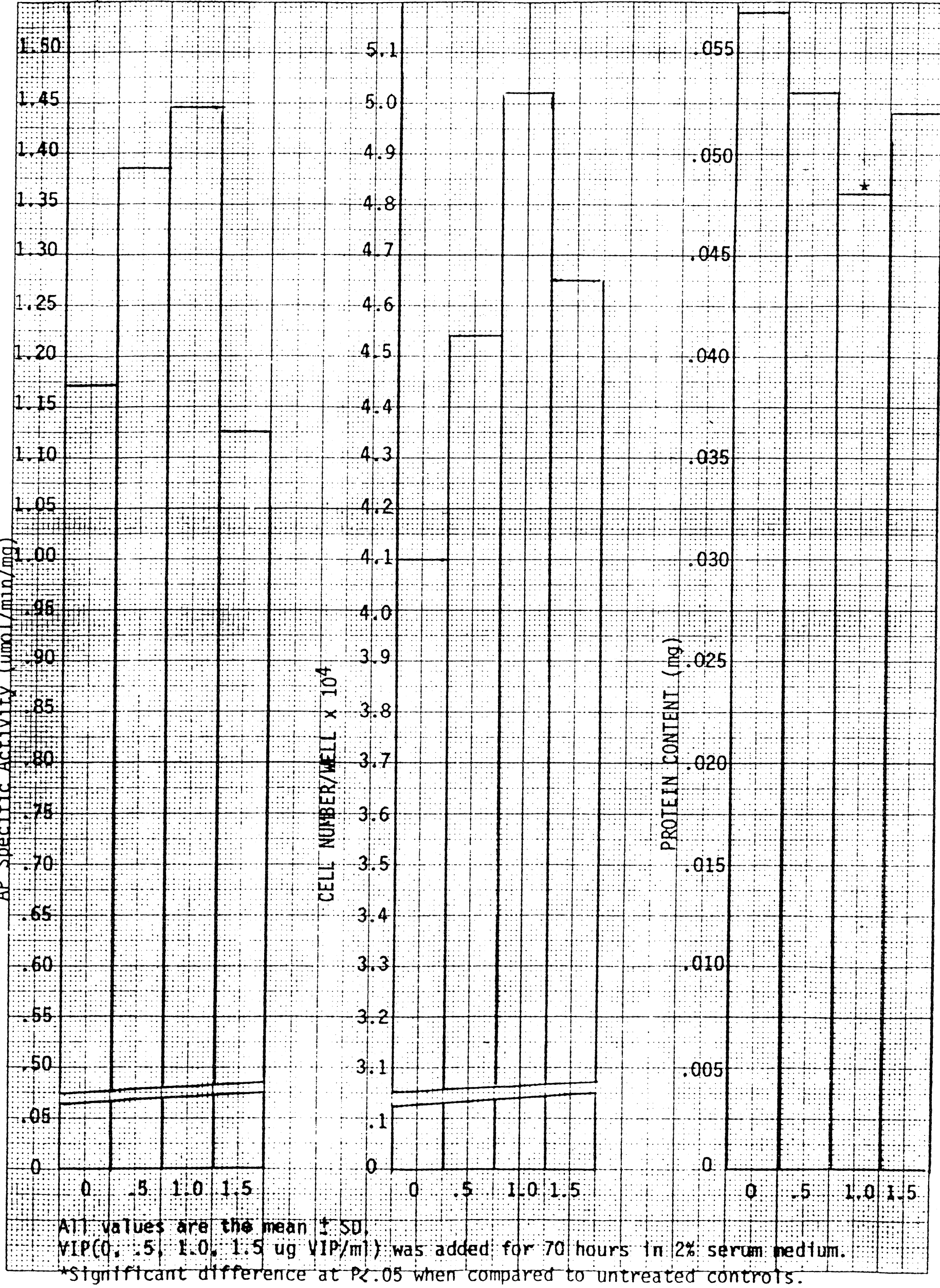




\section{DISCUSSION}

This study shows that VIP and NGF has a direct effect on osteoblasts in culture. Even though differentiation is coupled to growth arrest, the arrest of growth does not necessarily result in differentiation. Therefore, when studying the effect of NGF and/or VIP on ROS $17 / 2.8$ celis both growth (cell number) and differentiation (AP Sp Ac) were investigated. However, under the conditions of experiment \#1, the effect was small, when compared to the untreated control using the T-test.

The effect of VIP was more pronounced in the presence of IBMX and NGF, which antagonize it. This is apparent when the 3-way ANOVA was calculated; not only was there an effect of the VIP, NGF and IBMX alone, but also an interaction ( $\mathrm{axb}$ ) on the AP Sp Ac, cell number and protein content.

Experiment \#1 indicates that the addition of the phosphodiesterase inhibitor, IBMX, either alone or in combination with other agents tends to cause a decrease in specific activity of alkaline phosphatase. These results following the addition of IBMX agree with previous findings in the laboratory (Majeska and Rodan, 1982b) .

Experiment \#2 was designed to increase the experimental time period from the 60 hours in experiment \#1 to 96 hours in experiment \#2, to investigate further the effect of the agent on cell growth. Another important alteration in experiment \#2 design was a decrease in the concentration of serum to $0.2 \%$ FBS to reduce its effects when examining the influence of VIP and NGF on the growth and maturation of ROS 17/2.8 cells. This is important because the presence of 
serum adds a complicating factor because serum binds and contains many growth and maturation factors. Of course, a serum free medium would eliminate the complicating factor of serum, but also adds a different factor, which is the difficulty for cell growth and maintenance.

Other relevant changes in experiment \#2, are that VIP was given in one dose, the NGF concentration was increased and there was a control on every plate. However, experiment \#2 was inconclusive; the difference in control values may be due to the relatively small sample size and large SD.

Therefore, Experiment \#3 was designed to increase the sample size and to investigate various concentrations of VIP. The experimental design of experiment \#3 was similar to Experiment \#1 with respect to serum concentration and plating density. The results of experiment \#3 support the results of experiment \#1: addition of VIP in the same concentration range (0.5-1.0 ug VIP/ml), increased AP Sp Ac, cell number, and decreased the protein content. At the highest concentration tested ( $1.5 \mathrm{ug} V I P / m I)$ the effect was reduced.

The biological effect was unexpected. The effects in the presence of IBMX appear to be the opposite of what one might expect. Previous studies showed that PTH and isoproterenol increase CAMP and decrease AP in ROS 17/2 cells. Since VIP increased CAMP in bone and human osteosarcoma cells, one might expect an inhibition of AP in ROS 17/2.8 cells. Since VIP antagonized the IBMX inhibitory effect on AP, its action may not have a simple relationship to changes in cAMP levels. In this study VIP increased the AP Sp Ac. Also, Hohmann and Tashjian (1984) reported that VIP increased cAMP in the 
human osteosarcoma cells. Hohmann and Tashjian (1984) have routinely used IBMX and found that IBMX stimulated CAMP. Vasoactive intestinal peptide and IBMX enhanced the production of CAMP; and IBMX potentiated the resorptive response to low concentrations of VIP.

In this study, the effects of VIP and NGF were found to be small, suggesting that the ROS cells are low in receptors for these agents. This may be a property specific to the ROS 17/2.8 clone. Grigoriadis et al. (1985) reported on the subclone heterogeneity of the ROS cells. Analysis of mixed osteoblastic cell populations or other cloned osteoblastic lines may yield greater responses. In that case, selection of cells on the basis of response and/or number of receptors for VIP and/or NGF, may be useful to study the direct effect of VIP and NGF on osteoblasts.

Two postulated general roles of the nervous system in mechanically induced tissue remodeling are: 1) The stimulated nerves could dilate capillaries at compression sites, leading to rapid release of inflammatory cells that actively participate in the invasion of the hyalinized zones. 2) A direct effect of a neurotrophic substance, such as VIP which is secreted from the nerve, causes a response in the osteoblast. The results reported in this study are consistent with this hypothesis. Also, Hohmann and Tashjian's (1984) findings of functional receptors for VIP on human osteosarcoma cells (SaOs-2), and the finding that VIP stimulates bone resorption (Hohmann et al., 1983); which further supports the proposed interaction of osteoblasts and osteoclasts (Rodan and Martin, 1981). 


\section{Summary and Conclusions}

This investigation was undertaken to assess a direct neural involvement in osteogenesis. Two neurotrophic factors, NGF and VIP had the following effects on the ROS $17 / 2.8$ cells.

1. VIP increased the AP Sp Ac and cell number, when measured sixty hours following the initial addition of five doses of $0.165 \mathrm{ug} / \mathrm{ml}$ at 12 hour intervals. This condition decreased the protein content. VIP had a similar effect when added in a single dose of $0.825 \mathrm{ug} / \mathrm{ml}$.

2. VIP increased the AP Sp Ac and cell number, and decreased the protein content when measured seventy hours following the addition of a single dose $(0.50 \mathrm{ug} / \mathrm{ml}$ and $1.0 \mathrm{ug} / \mathrm{ml})$.

3. NGF inhibited the AP Sp Ac and increased the cell number and protein content when measured sixty hours following the addition of a single dose $(0.025 \mathrm{ug} / \mathrm{ml})$.

4. IBMX, either alone or in combination with other agents decreased AP Sp Ac.

5. The effect of VIP in increasing AP Sp Ac was more pronounced in the presence of IBMX and NGF.

These results are consistent with the hypothesis that the osteoblast responds directly to the neurotrophic substances VIP and NGF. 


\section{References:}

Ashton, B.A., Al len, T.D., Howlett, C.R., Eaglesom, C.C., Hattoric, A. and Owen, M., Clin Orthop 151: 294-307 (1980).

Bacq, Z.M., Am J Physiol 95: 601-604 (1936).

Becker, R.0., Nature 235: 109-111 (1972).

Bisgard, J.D., Ann Surg 97: 374-380 (1938).

Brenneman, D.E. and Eiden, L.E., Proc Natl Acad Sci 83: 1159-1162 (1986).

Bueker, E.D., Anat Rec 102: 360-390 (1948).

Cannon, W.B., Newton, H.F., Bright, E.M., Menkin, V. and Moore, R.M., Am J Physiol 89: 84-107 (1929).

Chihara, K., Iwasaki, J., Minamitani, N., Kaji, H., Matsukura, S., Tamaki, N., Matsumoto, S. and Fujita, T., J Clin Endocrin Metab 54: 773-779 (1982).

Chihara, K., Kaji, H., Minamitani, N., Kodama, H., Kita, T., Goto, B., Chiba, T., Coy, D.H. and Fujita, T., J Clin Endocrin Metab 58: 81-86 (1984).

Coulombre, A.J., Johnston, M.C. and Weston, J.A., Dev Biol 36: F1-F5 (1974).

Corbin, K.B. and Hinsey, J.C., Anat Rec 75: 301-317 (1939).

Douglas, B.S., Aust Paediat J 8: 86-89 (1972).

Drachman, D.B., Ann NY Acad Sci 228: 3-5 (1974).

Dubner, R., Sessle, B.J. and Storey, A.T. (eds.), The Neural Basis of Oral and Facial Function Plenum Press, New York, 1978, pp. 379-390.

Ekstrom, J. and Olgart, L., Acta Physiol Scand 126: 25-31 (1986).

Fahrenkrug, J., Digestion 19: 149-169 (1979).

Frazier, W.A., Boyd, L.F., Szutowicz, A., Pulliam, M.W. and Bradshaw, R.A., Biochem Biophys Res Comm 57: 1096-1103 (1974).

Fuxe, F., Hokfelt, T., Said, S.I. and Mutt, V., Neurosci Lett $\underline{5}$ : 241-245 (1977).

Granot, E., Deckel baum, R.J., Schiller, M., Okon, E., Goder, K., Landau, H. and Bloom, S.R., Am J Dis Child 137: 1203-1204 (1983).

Greene, L.A. and Shooter, E.M., Ann Rev Neurosci 3: 353-402 (1980).

Grigoriadia, A.B., Petkovich, P.M., Ber, R., Aubin, J.E. and Heersche, J.N., Bone $\underline{6}$ : 249-256 (1985).

Guth, L., Neurosci Res Prog Bull 7: 1-73 (1969). 
Harris, R.I. and McDonald, J.L., J Bone Joint Surg 18: 35-45 (1936). Hohmann, E.L., Levine, L. and Tashjian, A.H., Jr., Endocrinology 112: 1233-1239 (1983).

Hohmann, E.L. and Tashjian, A.H., Jr., Endocrinology 114: 1321-1327 (1984). Illingworth, C.M., J Pediat Surg 9: 853-858 (1974).

Kaplan, S.J., Holbrook, C.T., McDaniel, H.G., Buntain, W.L. and Crist, W.M., Am J Dis Child 134: 21-24 (1980).

Laburthe, M., Couvineau, A., Rouyer-Fessard, C., Mol Pharmacol 29: 23-27 (1986).

Libbin, R.M., Person, P., Papierman, S., Shah, D., Nerud, D. and Grob, H., J Morph 159: 439-452 (1979).

Majeska, R.J. and Rodan, G.A., J Biol Chem 257: 3362-3365 (1982a).

Majeska, R.J. and Rodan, G.A., Calcif Tiss Int 34:59-66 (1982b).

Majeska, R.J., Rodan, S.B. and Rodan, G.A., Endocrinology 107:1494-1503 (1980).

Marie, J.C., Hui-Bon-Hoa, D., Jackson, R., Hejblum, G. and Rosselin, G., Regul Pept 12: $113-123(1985)$.

Matsushita, N., Kato, Y., Katakami, H., Shimatsu, A., Yanaihara, N. and Imura, H., J Clin Endocrinol Metab 53: 1297-1300 (1981).

McSheehy, P.M. and Chambers, T.J., Endocrinology 118: 824-828 (1986).

Neufeld, D.A., J Exp Zool 212: 31-36 (1980).

Polak, J.M. and Bloom, S.R., In: Said, S.I. (ed.), Vasoactive Intestinal Peptide, Raven Press, New York, 1982, pp. 107-120.

Rodan, G.A. and Martin, T.J., Calcif Tissue Int 33: 349-351 (1981).

Rosenthal, L.J., Reiner, M.A. and Bleicher, M.A., Pediatrics 64: 1-3 (1979).

Said, S.I. and Mutt, V., Science 169: 1217-1218 (1970).

Saide, J.D., Murphy, R.A., Canfield, R.E., Skinner, J., Robinson, D.R.. Arnason, B.G.W. and Young, M., J Cell Biol 67: 375a (1975).

Scott, J. and Baum, B.J., Biochim Biophys Acta 847: 255-262 (1985).

Singer, M., Am Zool 18: 829-841 (1978).

Singer, M., Quart Rev Biol 27: 169-200 (1952).

Singer, M., J Exptl Zool 101: 299 (1946).

Singer, M. and Craven, L., J Exp Zool 108: 279-308 (1948). 
Spector, T., Anal Biochem 86: 142-146 (1978).

Sundler, F., Hakanson, R. and Leander, S., Clin Gastroenterol 9: 517-543 (1980). Teitelbaum, S.L., Andres, R.Y., Cooke, N.E., Hahn, T.J. and Kahn, A.J., Calcif Tiss Res 26: 203-208 (1978).

Tsukada, T., Horovitch, S.J., Montminy, M.R., Mandel, G. and Goodman, R.H., DNA 4 : 293-300 (1985).

Uddman, R., Fahrenkrug, J., Malm, L., Alumets, J.,Hakanson, R. and Sundler, F., Acta Physiol Scand 110: 31-38 (1980).

Varon, S.S. and Bunge, R.P., Ann Rev Neurosci 1: 327-361 (1978).

Weis, J.S. and Weis, P., J Exp Zool 174: 73-78 (1970).

Yntema, C.L., J Exp Zool 140: 101-124 (1959). 